West Chester University

Digital Commons @ West Chester University

University Libraries Faculty Publications

University Libraries

$4-29-2021$

\title{
"Information Has Value" in Business Library Instruction: Approaching the Frame Three Ways
}

\author{
Grace Liu \\ West Chester University of Pennsylvania, yliu@wcupa.edu \\ LuMarie Guth \\ Western Michigan University, lumarie.guth@wmich.edu \\ Ilana Stonebreaker \\ Indiana University - Bloomington, is1@iu.edu
}

Follow this and additional works at: https://digitalcommons.wcupa.edu/lib_facpub

Part of the Library and Information Science Commons

\section{Recommended Citation}

The final revised pre-published version is available on this repository.

This Article is brought to you for free and open access by the University Libraries at Digital Commons @ West Chester University. It has been accepted for inclusion in University Libraries Faculty Publications by an authorized administrator of Digital Commons @ West Chester University. For more information, please contact wcressler@wcupa.edu. 


\section{"Information Has Value" in Business Library Instruction: Approaching the Frame Three Ways}

Grace Liu ${ }^{\mathrm{a} *}$, LuMarie Guth ${ }^{\mathrm{b}}$, Ilana Stonebraker ${ }^{\mathrm{c}}$

${ }^{a}$ West Chester University, PA, USA; ${ }^{b}$ Western Michigan University, Kalamazoo, MI, USA;

'Indiana University, Bloomington, IN, USA

Address Correspondence to Grace Liu, Assistant Professor, Business and Faculty Services

Librarian, West Chester University, FHG Library, 25 W Rosedale Ave, West Chester, PA 19382,

USA. E-mail: yliu@wcupa.edu 
INFORMATION HAS VALUE 2

\title{
"Information Has Value" in Business Library Instruction: Approaching the Frame Three Ways
}

\begin{abstract}
:
This article explores business information literacy applications of the "Information Has Value" frame from the ACRL Framework for Higher Education. The authors share three approaches with the corresponding lesson plans to integrate the frame from three distinctive perspectives: (a) information has value as a commodity, (b) information has value in decision-making, and (c) different voices have their unique value.
\end{abstract}

Keywords: information has value, business information literacy, ACRL Framework

\section{Introduction}

Since the adoption of the Framework for Information Literacy for Higher Education (the Framework) in 2016, business librarians have explored ways to incorporate the Framework into business library instruction. An initial instinct when planning library instruction is to address all of the frames in a single session in hopes that students gain a broad understanding of information literacy principles. This article instead gives a deeper exploration of the Information Has Value frame, a uniquely relevant frame in business information literacy, and shares three approaches to integrate this frame into library instruction. The first approach regards information as a commodity and focuses on the concept of competitive information and assessing the value of competitive intelligence. The second approach discusses how to use the Information Has Value frame as a tool of critical analysis in processes of reflection for decision-making. The third approach stresses that different voices have their unique value and it is researchers' responsibility to seek multiple perspectives and make under-represented or systematically marginalized voices heard. 


\section{INFORMATION HAS VALUE 3}

The intent of constructing the frame three ways is to examine the opportunities for depth in exploring a single frame in the Framework. As described in the Framework, librarians are encouraged to design their own learning outcomes based on their institutional and instructional contexts (ACRL, 2016). The spirit of the Framework can go beyond specific knowledge practices and dispositions. In the following sections, we will examine how the Information Has Value frame is explored in library instruction for different disciplines, particularly for business library instruction. We will then describe the three approaches to incorporating Information Has Value and give an example of a lesson for implementing each approach. Finally, we will discuss how a deep approach affects the understanding of the information literacy concepts as applicable beyond the classroom setting.

\section{Literature Review}

In order to situate our discussion of Information Has Value in context, we first looked at how it had been described in the existing library literature. Although the dominant conversation regarding Information Has Value focuses on copyright education, the frame is also used to address media literacy (Bussell, 2018; Haggerty \& Scott, 2019; Phillips, 2019). In a STEM setting, the frame is used to present the value of scientific research and how scientific information is used to influence people (Belzowski \& Bugajski, 2018; Bohémier, 2019). In the social sciences, this frame is used to address information access and privilege (Cook, et al., 2017). There has also been a rising discussion over the role of the Information Has Value frame in connecting information literacy to social justice (Battista et al., 2015; Saunders, 2017; Gregory \& Higgins, 2017).

Previous research has found that the frame Information Has Value is highly regarded by both business librarians and business faculty. A national survey conducted by Guth and Sachs 


\section{INFORMATION HAS VALUE 4}

(2018) on business librarians' adoption of the Framework reported that the Information Has Value frame was incorporated by $67 \%$ of respondents (40 out of 60 librarians), as compared to other frames, including Research as Inquiry (73\%; 44 librarians), Searching as Strategic Exploration (73\%; 44 librarians), Authority is Constructed and Contextual (72\%; 43 librarians), Scholarship as Conversation (48\%; 29 librarians), and Information Creation as a Process (42\%; 25 librarians). Additionally, a multi-institutional study of faculty in the business discipline found that business faculty ranked Information Has Value as the most important frame for student academic success (Bielat et al., 2017).

The Information Has Value frame, particularly the concept of information as a commodity is directly related to financial literacy. Gass and Garczynski (2016) used the Information Has Value frame to bridge information literacy and financial literacy, and stressed the value of securities market information and the cost of market misinformation. They organized a workshop designed around the Information Has Value frame and asked participants to compare different financial information sources of a selected company. The workshop facilitated meaningful discussions on the value and inherited biases of information sources and how to make informed financial decisions based on varied sources (Gass \& Garczynski, 2016, p. 59).

Very early after the adoption of the ACRL Framework, business librarians gravitated towards Information Has Value as a useful frame, returning to it repeatedly as a key point of engagement with business students. Spackman (2016) stressed the relevance of the Information Has Value frame in client-based experiential learning programs. Spackman states that "the realworld learning experience offers an opportunity for instruction on the differences between primary and secondary research, including the relative costs in money and time involved" (p. 


\section{INFORMATION HAS VALUE 5}

263). According to Spackman, business experiential learning programs can facilitate a deeper conversation over Information Has Value through the lens of information as a commodity. For example, librarians can discuss the public non-institutional prices of research reports versus what the library pays, and why vendors might be willing to provide the library discounts. Librarians can further lead the discussion through the lens of copyright by talking about the risks that vendors can expose themselves to when selling their information, why contract and licensing terms exist, and what types of uses are and are not legally admissible (p. 263). In addition to experiential learning programs, the flipped classroom instruction model may also offer more opportunities for the discussion of framework concepts, particularly Information Has Value (Tingle, 2018). The flipped classroom opens up more time for engaged conversation. Tingle found that "students are receptive to developing some of the knowledge practices and dispositions associated with the [Information Has Value] frame” (p. 195).

Business librarians consider Information Has Value a useful frame beyond information as a commodity and copyright education. Stonebraker (2016) showed the value of information toward informed leadership and encouraged students to make better decisions using information. Jefferson (2017) linked the Framework to Fink's Taxonomy for Significant Learning in business research courses. Jefferson prompted students to reflect upon how information added value to their personal experience and reminded the students of their privilege in accessing information through the library and online. Linking the Information Has Value frame to Fink's "caring" taxon, Jefferson highlighted that "by reflecting on their value of knowledge, students realize they care about accessing reliable information to make better decisions" (p.12). Although the Information Has Value frame can be explored in many ways, Badke (2020) cautions us that "probably the true value of information is what it can do for us to enable our advancement in the 


\section{INFORMATION HAS VALUE 6}

world. This can be a disjunct from the monetary cost in that what we may have to pay may not match the value of our resources when it comes to human advancement" (p. 36).

While Information Has Value has been found to be salient for business librarians and business faculty, previous work often described a single approach, never an exploration of how to approach the frame in more than one way or context. In the next section, we will share three approaches in addressing the Information Has Value frame. We will highlight the rationales behind the lesson plans and active learning activities designed around the frame and will discuss the assessment results when applicable. This approach helps cement the ways in which the Information Has Value frame is helpful in multiples contexts, particularly with business students. For each, we will describe how the approach fits within the definition of the frame, the rationale for the approach, the lesson plan, and then the associated assessment.

\section{Three Approaches to Addressing Information Has Value}

\section{Approach One: Information Has Value as a Commodity}

The Information Has Value frame lists dimensions of value for information including as a "commodity" and a "means of influence." A disposition for the frame states that information literate people, "value the skills, time and effort to produce information" (ACRL, 2016). The use of information to make competitive decisions in business is crucial and is the lens through which many academic business assignments address information literacy.

This lesson was created for a first-year course orienting business students to campus resources required of business majors in lieu of a general first-year experience course at Western Michigan University. The course featured guest speakers in each session demonstrating campus services with a special focus on their relevance to business students. The lesson is a part of a 


\section{INFORMATION HAS VALUE 7}

guest instruction session from the librarian to orient students to library resources and services. A shortened version was also delivered in a marketing research course with juniors and seniors.

Students are given a packet (see Appendix 1) with five descriptions of information sources: 1) primary consumer research, 2) news sources, 3) industry/market reports, 4) official government data, and 5) an expert consultant. Each description includes information on cost and impact derived from the textbook used for the marketing research course. Students are asked to place different types of market research sources in Nandakumar's (2018) Cost-Impact Matrix, and evaluate them by the cost (the price of a report, time put into gathering data, or level of experience and expertise needed) and by the impact on the decision-making process (p. 87). In the longer version of the lesson, with the first-year course, the students are first shown an 8minute $\mathrm{CNBC}$ video in which the sources are used to demonstrate growth trends in the skincare industry. The CNBC video was chosen because of the deliberate use of and reference to sources in their argument - sources also commonly used by business students. After the students finish placing the sources on the matrix, the responses are entered into an online form. Aggregate results are then presented to the class, and justifications for consensus and disagreement are discussed. For example, news sources may be considered low or high cost depending on the time put into gathering them, and whether or not paid subscriptions to news aggregators are used.

The librarian then reveals the quadrant labels and discusses each quadrant. Information that is high-cost and low-impact is "Deprioritized." Information that is low-cost and low-impact is "Nice to Have," but not crucial to the decision-making process. Information that is low-cost and high-impact is a "Quick Win" and should be gathered to ensure access to the general knowledge. Finally, information that is high-cost and high-impact is a "Strategic Win." This 


\section{INFORMATION HAS VALUE 8}

information demands a lot of resources to acquire and is thus less available to competitors. It can provide an edge when making a business decision.

\section{[INSERT TABLE 1 ABOUT HERE]}

The responses from first years $(n=37)$ and juniors/seniors $(n=117)$ suggest interesting changes in students' perceptions of the value of primary market research sources as they move through the business curriculum. $76 \%$ of juniors and seniors ranked primary consumer research as high impact (calculated as "Quick Win" plus "Strategic Win”) versus only 55\% of first years. Conversely, news sources lost impact as students moved through the curriculum with $46 \%$ of first years and $25 \%$ of juniors and seniors ranking it as high impact. Additionally, there was a greater understanding of the high cost of collecting quality primary research by juniors and seniors. $65 \%$ of juniors and seniors classified primary research as a high cost whereas only $27 \%$ of first years did. This lesson demonstrates the commercial value of information and the importance of gathering information beyond what is easily accessible for a strategic advantage.

\section{Approach Two: Information Has Value in Decision-Making}

According to the Framework, the value of information can be leveraged "by individuals and organizations to effect change and for civic, economic, social, or personal gains" (ACRL, 2016). Information serves as a "means of education, as a means to influence, and as a means of negotiating and understanding the world" (ibid). While our first example focused on information as a means of commodity, this lesson plan will focus on the concept of information being valuable in a decision-making process in a socio-economic context, for example, in assessing the feasibility of a collaboration between the university and one of three companies.

This lesson plan was implemented as part of a fall course that serves as an introduction to management for freshmen who were directly admitted to the Krannert School of Management at 


\section{INFORMATION HAS VALUE 9}

Purdue University. The instructor for the credit-bearing course was a business librarian.

Understanding public and private company information was one of the learning objectives of the course. The in-class assignment was specifically designed to combine both the finding of relevant information and the weighing of the different types of information, in order to decide what aspects of the information are most important for the decision at hand.

In the group in-class activity, branded as a group challenge (see Appendix 2), students are given a list of companies to investigate. They need to find out how large the companies are in terms of employees, assess the financial health of the company, and find some recent press releases. From this information, students then evaluate each of the companies separately on their size, outlook, fit for the project, and transparency, meaning how easy or how hard it is to find the information about the companies. Students watch videos about finding this information before class and they know that they will have to find this information based on a previous assignment. To make things easier to compare, the students are asked to give each company a 1-10 score on each of the metrics.

Students are then called to come together to rank, as a group, the importance of each aspect of company information (size, outlook, transparency, fit) in this specific design context and write a 50 to 100 word rationale and justification. Usually, students feel that the financial outlook of the company is most important, followed by the size of the company, because they assume that a large company is more likely to hire more students, so it is more feasible for the university to partner with.

Finally, each group of students writes a minimum 100-word recommendation on which is of the companies the institution should partner with. They can base this decision on size, outlook, transparency, fit, or all four. This is where the decision-making lesson becomes clear. Many 
INFORMATION HAS VALUE 10

students will choose a company that does not fit the metrics they discussed as most important in the previous question. For example, a group might think the outlook is important, but they then choose the company with the worst outlook because they find some good quotes from their website, so they leverage fit instead. In another example, a group may rank institutional fit highly, but base their decision on the size or the number of employees.

Different versions of this assignment were used over four fall semesters. Assessment of this course was covered in another paper (Stonebraker \& Howard, 2018). As discussed in the paper, at midterm, students were asked to assess their team's performance via an in-class activity $(n=38)$. Responses were then coded independently for variables and then coded by an independent reviewer using the variables chosen. All groups said the class had improved their decision-making. Students mentioned they learned more about making decisions in teams from having taken the course, including making better decisions $(n=7)$, faster decisions $(\mathrm{n}=4)$, and more informed decisions $(n=14)$. A large group also indicated that they better understood bias and fallacies $(n=10)$.

This project is designed specifically to be time-consuming and overly burdened by finding information. Student groups assess a specific metric (fit, size, outlook, transparent) as the most important. But when it comes to making a decision, they neglect that information has value for their decision-making. Student groups are so focused on finding the information, which can be overwhelming, that they often forget the reason that they are finding the information in the first place. If you ask a student if they make evidence-based decisions, they often would say yes, but this exercise elucidates how information overload sometimes leads to becoming so focused on finding the information that the decision-making criteria are abandoned for an impressive looking chart. This assignment serves as a reminder for business students that often we only see 
INFORMATION HAS VALUE 11

information in the context of its value as a commodity and only later see that information can also be used in the context of a specific decision.

\section{Approach Three: Different Voices have their Unique Value}

This final approach addresses one of the knowledge practices in the Information Has Value frame: "understand how and why some individuals or groups of individuals may be underrepresented or systematically marginalized within the systems that produce and disseminate information," and emphasizes the disposition of "value the skills, time, and effort needed to produce knowledge," as well as "see themselves as contributors to the information marketplace rather than only consumers of it" (ACRL, 2016).

This lesson plan was designed for a first-year experience business class. It was the first year that the West Chester University of Pennsylvania (WCU) offered a first-year experience course for business or pre-business majors. The course intended to set the stage for first-year business students by engaging in a real-world research project and developing skills in social entrepreneurship and community engagement. Students are introduced to the various programs offered within the College of Business and Public Management for better understanding of why WCU approaches its curriculum through the lens of the interdisciplinary "liberal arts tradition." The library instruction session is integrated into this class to guide students through the research process in developing a business idea that addresses a campus issue. Four breakout sections are organized around four different issues on campus: sustainability, student success, wellness, and diversity \& inclusion. The faculty expect that students are able to research what is happening on other college campuses concerning these issues, which entails more of a focus on general media rather than peer-reviewed literature. 


\section{INFORMATION HAS VALUE 12}

The instructional design of the library session incorporates the Information Has Value frame through an active learning activity - Group Role Play: Getting your Voice Heard (see Appendix 3). The activity assigns four different roles: a professor, a university administrator, a student, and an organization member. These four roles represent four different voices that often contribute to the discussion of campus issues. The prompts for the role-play discussion guide students to think through how the information provided by different roles or contributors is published, distributed, and shared. This activity encourages students to recognize that different voices have their unique value and understand that some voices may be underrepresented or systematically marginalized due to established information publication and dissemination mechanisms.

Following the role-play activity, the librarian explains how to find different voices, calling attention to what is available in the library and what may be hard to find in the library. For the voices that are not often found in library resources, students are encouraged to search public media. The librarian explains how to purposefully design the search terms to find marginalized voices and demonstrates how to conduct both a library database search and an effective Google Search to find different voices. With the recap of the research process and some take-aways, the librarian encourages students to be flexible, creative, and persistent in information searching and to intentionally analyze information stakeholders and think about marginalized voices. The librarian also motivates students to recognize themselves as information contributors and to believe they could leverage the value of information to affect changes on our campuses and in our communities.

In the assessment survey, students are asked to share their takeaways and particularly their understanding of Information Has Value after the library session. Some of the key points 
INFORMATION HAS VALUE 13

mentioned by students regarding Information Has Value include: “information has a deeper meaning," "all kinds of information have a different value," "it is important to do your due diligence to find the information that is valuable," "in-depth research serves a great value to the progression of knowledge and life in general," and we must "explore and appreciate the information," and "giving credit to people who create information." This approach offers students opportunities to think about the value of information beyond monetary value and consider information as a valuable way to gather the voices of others as well as their own.

\section{Limitations and Future Work}

We have discussed our perspectives and approaches to integrating the Information Has Value frame from multiple institutional contexts. This paper is by no means exhaustive and does not represent all ways that librarians could approach Information Has Value. While the assessment is explored for each of the approaches, this paper is intended to be a qualitative, not a quantitative study of the Framework. It presents assessment as a means of validating the lesson plan's usefulness, not as a way of validating the use of the Framework. This paper does not assess, for example, whether the adoption of the Framework is more successful pedagogically than no adoption of the Framework at all. The three approaches involve in-class activities, but we do not explore whether similar approaches could be made in an online method.

Previous studies have shown that Information Has Value is most important to business educators, but it is also important to non-business educators as well. While we have tried in this paper to be very expansive in terms of our analysis of the Framework, there may be other approaches outside of business librarianship that may be useful.

This paper does not explore the other five frames of the Framework. We would further encourage those in the librarianship community to put forward similar work for these other 
INFORMATION HAS VALUE 14

frames, exploring each of them individually. Information literacy education is an iterative, crosscollaborative, and multi-faceted experience. It is not our intent to put forward lesson plans that "check all the boxes", however, these approaches may also be useful for exploring other frames, such as Research as Inquiry (approach two) and Authority is Constructed and Contextual (approach three).

\section{Conclusion}

When first confronted with the Framework, it is easy to be overwhelmed by the challenges of building a complex understanding of information literacy in a college student. Some librarians have the opportunity to embed tiered instruction at different stages of the curriculum whereas others may only be able to conduct one-shots scattered across courses and sections based on relationships with individual business instructors. Additionally, librarians may feel confined to demonstrating business databases and feel less control over building their own learning activities.

However, a carefully designed activity addressing Information Has Value can help a student look beyond checking boxes for source requirements for an assignment and understand the real-world value of information in business. In this paper, we give three such activities and encourage creativity among business librarians in finding new ways to teach the frame. It is important for business students to find impactful sources, determine the parameters of the problem, and gather diverse voices beyond their own understanding.

\section{References}

Association of College and Research Libraries (ACRL). (2016). Framework for Information Literacy for Higher Education. http://www.ala.org/acrl/standards/ilframework 
INFORMATION HAS VALUE 15

Badke, W. E. (2020). How I (Try to) Teach the Framework. Online Searcher, 44(3), 35-37.

Battista, A., Ellenwood, D., Gregory, L., Higgins, S., Lilburn, J., Harker, Y. S., \& Sweet, C. (2015). Seeking social justice in the ACRL Framework. Communications in Information Literacy, 9(2), 6.

Belzowski, N., \& Bugajski, K. (2018). The Utility of Social Media for Teaching Information Has Value. https://scholar.valpo.edu/cgi/viewcontent.cgi?article $=1080 \&$ context $=$ ccls_fac_pub

Bielat, V., Guth, L., Arnold, J., Perez-Stable, M., \& Vander Meer, P. (2017, May). Reining in information literacy instruction: Using faculty survey data to guide the process. Paper presented at LOEX 2017, Lexington, Kentucky. https://scholarworks.wmich.edu/library presentations/13/

Bohémier, K. A. (2019). Information Has Value: Teaching with the ACRL Framework in a STEM Setting. Science \& Technology Libraries, 38(1), 72-82.

Bussell, H. (2018). Whose medium? Whose message?: A critical media literacy approach to "Information Has Value." In M. K. Oberlies \& J. Mattson (Eds.), Framing information literacy: Teaching grounded in theory, pedagogy, and practice (Vol. 2, pp. 171-184). Chicago: Association of College and Research Libraries.

Cook, D. B., Davila Greene, J., \& Swift, A. (2017). Information Has Value: A View from Three Institutions. http://scholarship.claremont.edu/cgi/viewcontent.cgi?article=1059\&context=library_staff

Gass, S., \& Garczynski, J. (2016). Information Has Value. The Library's Role in Supporting Financial Literacy for Patrons, 53. 
INFORMATION HAS VALUE 16

Gregory, L., \& Higgins, S. (2017). Reorienting an information literacy program toward social justice: Mapping the core values of librarianship to the ACRL framework. Communications in Information Literacy, 11(1), 14.

Guth, L., \& Sachs, D. E. (2018). National trends in adoption of ACRL information literacy guidelines and impact on business instruction practices: 2003-2015. Journal of Business \& Finance Librarianship, 23(2), 131-153. https://doi.org/10.1080/08963568.2018.1467169

Haggerty, K., \& Scott, R. E. (2019). Teaching copyleft as a critical approach to "Information Has Value". In A. Pashia \& J. Critten (Ed.), Critical Approaches to Credit-Bearing Information Literacy Courses (pp. 259-270). Association of College and Research Libraries.

Jefferson, C. O. (2017). Good for Business: Applying the ACRL framework threshold concepts to teach a learner-centered business research course. Ticker: The Academic Business Librarianship Review, 2(1).

Nandakumar, M. (2018). Lean product management: Successful products from fuzzy business ideas. Packt Publishing.

Phillips, G. A. (2019). "Information Has Value” and Beyond: Copyright Education within and around the Framework. http://d-scholarship.pitt.edu/37710/

Saunders, L. (2017). Connecting information literacy and social justice: Why and how. Communications in Information Literacy, 11(1), 15.

Spackman, A. (2016). Client-based experiential learning and the librarian: Information literacy for the real world. Journal of Business \& Finance Librarianship, 21(3/4), 258-273. https://doi.org/10.1080/08963568.2016.1226616 
Stonebraker, I. (2016). Toward informed leadership: Teaching students to make better decisions using information. Journal of Business \& Finance Librarianship, 21(3-4), 229-238. doi:10.1080/08963568.2016.1226614

Stonebraker, I., \& Howard, H. A. (2018). Evidence-based decision-making: awareness, process and practice in the management classroom. The Journal of Academic Librarianship, 44(1), 113-117.

Tingle, N. (2018). Taking care of business (before class): Information literacy in a flipped classroom. Journal of Business \& Finance Librarianship, 23(2), 183-198. https://doiorg.proxy-wcupa.klnpa.org/10.1080/08963568.2018.1510254 
INFORMATION HAS VALUE 18

\section{Appendix 1: CNBC K-Beauty Activity for Approach One}

Class Activity: CNBC K-Beauty

Student Guide:

Step 1: Watch the CNBC video "How K-Beauty Took over Global Skin Care"

(https://www.youtube.com/watch?v=rS6Ifm YecQ) and focus on how the video uses

information from different sources to inform their presentation of the skin care industry and market trends.

Step 2: Work individually, in pairs or in groups, with the activity packet to place 5 of the information sources from the video on a chart based on measurements of cost and impact of the information on the problem.

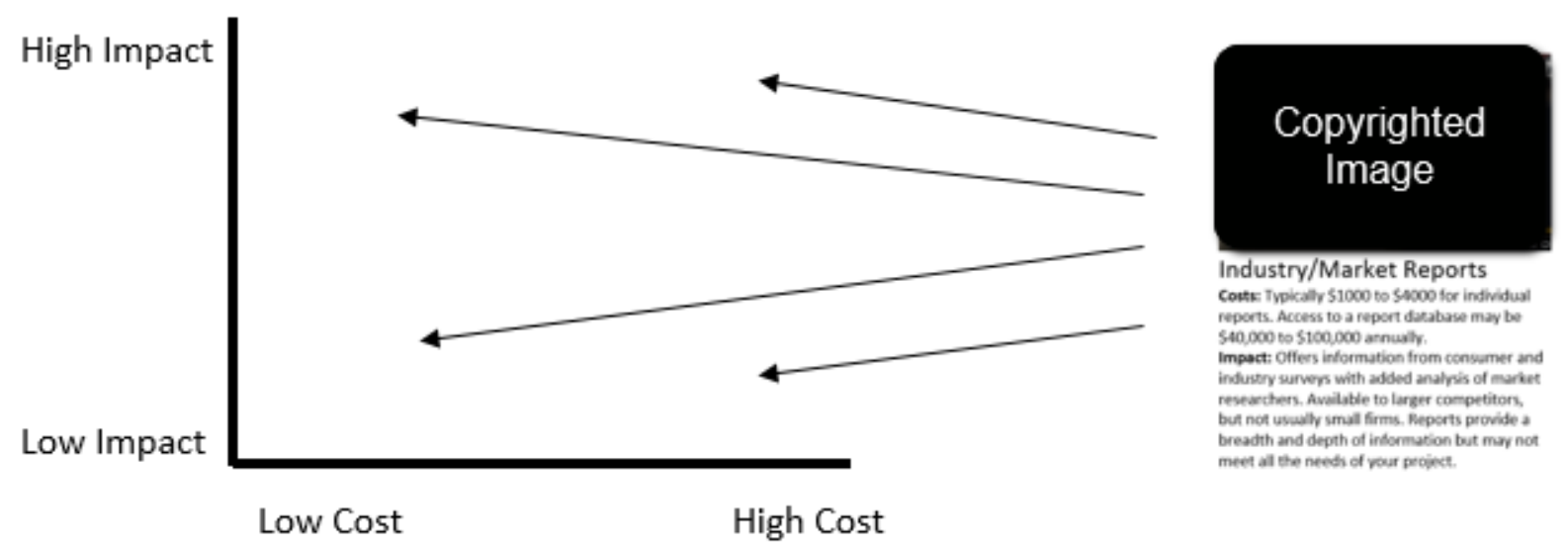

Step 3: Determine which quadrant of the chart each information source fits in and submit your results to the online activity form. (URL) 
INFORMATION HAS VALUE 19

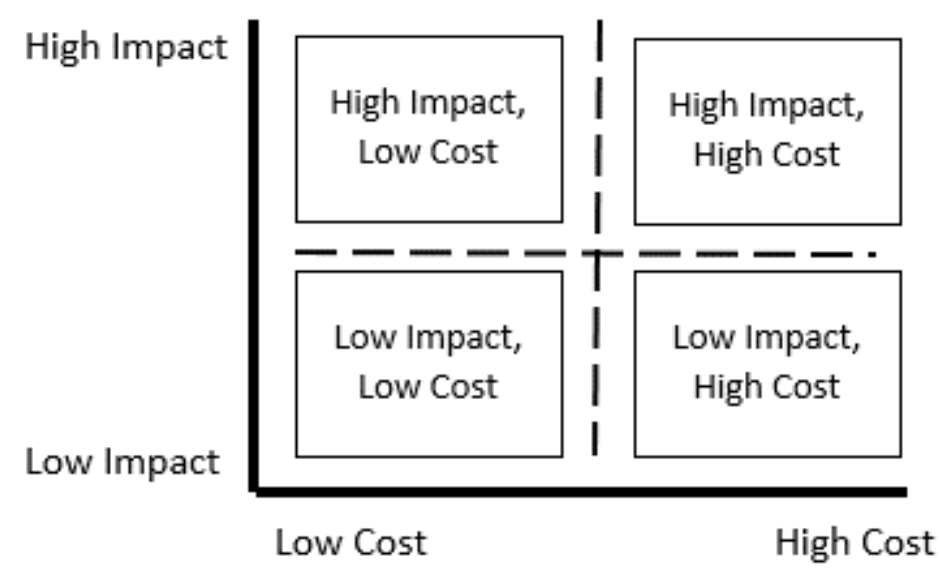


INFORMATION HAS VALUE 20

\section{Appendix 2: Group Challenge Activity and Worksheet for Approach Two}

\section{Group Challenge: Manufacturing is King}

\section{Project Description}

DUE: End of class today, to Blackboard. This is a group project that will be graded on its merits. It will be assessed for overall accuracy and completion. Put the name of your group members present in the comment box.

Purdue is an important part of the Greater Lafayette area economy, as it employs the largest number of people in the Greater Lafayette area. However, companies are also an important aspect of the economy. Manufacturing makes up the largest percentage of companies in the Greater Lafayette area.

For this Group Challenge, you will investigate the feasibility of a collaboration between Purdue and one of these large companies. Purdue plans to turn one of the larger fields on the outer edges of its campus into a research park. It wishes to invite one of the following companies to join the park. Due to space and budget limitations, it wants to choose only one collaborator. Purdue wants someone who will employ a large number of locals. These could be people previously employed by other companies, or unemployed members of the community. It also wants to choose a company with a good outlook for the long term (high probability by profitability), as this project will involve a sizable investment by Purdue in a new location.

\section{Research Tasks}

1. In one of the library databases (Mergent, Privco, or OneSource), find the report for each of the following companies: Wabash National, Alcoa, and Cargill. 


\section{INFORMATION HAS VALUE 21}

- In which database did you find this company?

- What kind of company is it... private, public, or subsidiary?

- How large is the company in terms of employees?

- Take a look at the past 3 years of net sales, net income, or revenue. Have these figures gone up or down?

- Google the company and find the recent news on the companies' website. Is there anything that would make them a good fit for Purdue? (Examples are awards, sustainability, growth, etc)

- Overall, how easy was it to find information on this company?

2. After you have completed this for the three companies, bring the information together and score the three competitors in terms of size of the budget, the outlook for the company, demographic fit, and transparency (1-10, with 1 being low). Put your numbers below.

- Wabash National

○ Size:

○ Outlook:

○ Fit:

○ Transparency (How easy it was to find information about the company):

- Alcoa

○ Size:

○ Outlook:

○ Fit:

- Transparency: 
INFORMATION HAS VALUE 22

- Cargill

○ Size:

○ Outlook:

○ Fit:

- Transparency:

3. As a group decides on a weighted ranking. What is most important, the size, the outlook, fit, or transparency? Write a 50-100 word rationale.

4. Decide: Write a minimum 100-word recommendation. Who should Purdue partner with? You can base this on size, outlook, fit, transparency, or all four.

Turn in on Blackboard what you have by the end of the class period.

\section{Suggestion for Group Research Logistics}

9:30-9:50 three group members each take a team and look up the companies in the financial databases. The fourth member finds company websites.

9:50-10:00 Group members check each other's work and also score companies

10:00-10:10 Members discuss questions 3 and 4.

10:10-10:20: One student writes up 3, another 4. Submit. 
INFORMATION HAS VALUE 23

\section{Appendix 3: Group Role Play Activity for Approach Three}

\section{Group Role Play - Getting your voice heard}

Roles:

\section{- Professor}

You are a professor who has studied student success issues for more than 20 years and you have developed your own theories and knowledge on this issue. How can you get your opinion known to others? Where can people find your opinion?

\section{- Administrator}

You are the Director of the Diversity and Inclusion Office at a University. You are responsible for developing university-level diversity strategies and programs. You want to share successful practices and approaches from your office. How can you get your experience shared? Where can people find the information from you?

\section{- Student}

You are a student at a university. You have concerns about recycling and waste reduction practices on campus. You don't think the current practice is sustainable and you believe as a student you have a great role to play to build a sustainable practice for your university. You want the voices from students to be heard. How can you make it happen? Where can people find your voices?

\section{- Organization Member}

You are a member of the National Association of College \& University Food Services and serve on the Nutrition Awards committee, which will select the Most Innovative Wellness \& Nutrition Program from your member institution each year. Your committee wants to 
INFORMATION HAS VALUE 24

highlight the award winners, where do you post the information? Where can people find the award winners from your insititution?

Engaged Conversations:

- Professor: How can you get your opinions known to others? Books, articles, social media (Facebook, Twitter feeds, etc.), TV programs, etc.? Does the information displayed in books and Twitter feeds have equal value? Can you find the scholar's books and articles with Google search? Can you access scholarly articles for free?

- Administrators: How can you get your experience shared? University’s website, newsletters, magazines, conferences presentations? Is it more likely for people to find your opinions online or more likely find it in a library?

- Students: How can you get your voices heard? Surveys, magazine articles, etc.? Is it easier or harder to find your voices than professors' or administrators' voices? Why?

- Association Members: Where do you post the information about the award winners? Websites, social media (Facebook, Twitter, etc.), etc.? What can you do to make the award-winning practices noticeable? Writing reports, sharing best practices, organizing conferences to grant the award, etc.? Do you think the winner would announce the winning through their own publication channels? Is it more likely for people to find your decisons online or more likely find it in a library? 